\title{
REFLEKSI KRITIS DALAM KEHUMASAN: STUDI TENTANG PENYELENGGARAAN KOMUNIKASI ORGANISASI BIRO HUMAS SEKRETARIAT DAERAH PROVINSI SUMATERA BARAT
}

\author{
Bary Fardan Siregar' ${ }^{1)}$, Asrinaldi' ${ }^{2}$, Jendrius ${ }^{3)}$ \\ 1) Kantor Imigrasi Kab. Agam, Kemenkumham RI; ryfardan@gmail.com \\ 2) Jurusan Ilmu Politik FISIP Universitas Andalas; asrinaldi.91@ gmail.com \\ 3) Jurusan Sosiologi FISIP Universitas Andalas; jendrius@yahoo.com
}

\begin{abstract}
ABSTRAK
Penelitian ini berangkat dari fenomena penyelenggaraan komunikasi pemerintahan oleh Biro Humas Sekretariat Daerah (Sekda) Provinsi Sumatera Barat yang bersifat searah. Hal ini menjadi menarik untuk dipelajari mengingat model penyelenggaraan komunikasi kehumasan kontemporer telah berkembang dan jauh berbeda dari bentuk lamanya. Sementara itu peraturan yang mengatur tata kelola kehumasan di lingkup pemerintahan telah terbit dari tujuh tahun yang lalu, namun Biro Humas Sekda Provinsi Sumatera Barat masih menerapkan model komunikasi searah. Penelitian ini menghasilkan beberapa simpulan utama dalam menjawab permasalahan yang ada. Pertama, Biro Humas Setda Provinsi Sumatera Barat tidak dapat menjalankan aktivitas kehumasan secara ideal menurut perundangan yang ada karena terdominasi oleh koalisi dominan. Hal tersebut menyiratkan humas adalah wadah untuk menunjukkan dan mempertahankan kekuasaan. Kedua, dominasi yang diterima menyebabkan biro humas disibukkan untuk menjaga reputasi koalisi dominan dari pemberitaan negatif. Ini membuat biro humas alfa dalam berpikir mewujudkan humas pemerintah yang modern. Ketiga, era industri pers dewasa ini semakin menjerat Biro Humas Sekda Provinsi Sumatera Barat. Ketergantungan antara biro humas dengan media, pun sebaliknya, menciptakan lingkaran kemunduran yang tak berkesudahan. Dalam hubungan tersebut, biro humas selalu takut jika ada pemberitaan negatif tentang koalisi dominan, sehingga ia 'berteman baik' dengan media cetak. Media cetak juga butuh pemasukan dan memiliki senjata ampuh untuk menjamin kebutuhannya terpenuhi-pemberitaan negatif.
\end{abstract}

Kata kunci: public relations, komunikasi searah, koalisi dominan, dominasi, hegemoni, komunikasi dua arah.

\section{ABSTRACT}

This study departed from the fact of one-way governmental communication shown by Biro Humas Sekretariat Daerah (Sekda) Provinsi Sumatera Barat. It was interesting to be learned because the model of public relations communication has changed and so much different from its old form. The regulation about governmental public relations has released since seven years ago, but Biro Humas Sekda Provinsi Sumatera Barat is still using one-way communinaction model. First, Biro Humas Sekda Provinsi Sumatera Barat could not operate public relations communication activity ideally according to the regulation caused by domination effect. It means that public relations is a arena in showing and struggling the power. Second, the domination caused Biro Humas Sekda Provinsi Sumatera Barat to keep away dominant coalition's reputation from negative news. This situation made Biro Humas Sekda Provinsi Sumatera Barat has no thought in making modern public realtions. Third, pers industrial makes it more complicated. The dependency among public relations and mass media creates an endless cycle of regression. In case, Biro Humas Sekda Provinsi Sumatera Barat feels scared if negative news of coalition dominant deployed in mass media-so then be friends. Mass media needs income and has the main weapon to guarantee their needs met-negative news.

Keywords: public relations, one-way communication, dominant coalition, domination, hegemony, twoway communication. 


\section{PENDAHULUAN}

Sejak memasuki era reformasi, Indonesia dihadapkan pada tantangan atas tata kelola pemerintahan lokal yang baik (good local governance). Soalan tersebut acap kali dikaitkan dengan masalah efektivitas serta efisiensi, terutama terkait masalah komunikasi massa yang diselenggarakan oleh organisasi pemerintahan. Sehubungan dengan itu, keberadaan humas pemerintah diketahui memiliki peran sentral dan strategis dalam dunia komunikasi massa. Kualitas penyelenggaraan aktivitas kehumasan di lingkup pemerintah akan berdampak besar pada kualitas pemerintahan itu sendiri.

Memahami humas pemerintah, James E. Grunig dalam Paradigms of Global Public Relations In An Age of Digitalisation (2009) menyatakan bahwa satu hal menonjol dari perubahan antara humas masa lampau dan kini terletak pada fungsi humas secara sempit. Humas di masa lampau lebih menitikberatkan peran sebagai juru bicara dari pihak yang diwakilinya dan memainkan model komunikasi satu arah. Sedangkan humas masa sekarang lebih mementingkan adanya komunikasi dua arah dan juga membuka diri untuk menerima masukan dan saran, serta berdiskusi untuk mencapai pemahaman yang optimal.

Untuk itu, dalam merespons perubahan dinamika penyelenggaraan aktivitas kehumasan di lingkungan pemerintah, Kementerian PANRB mengeluarkan Peraturan Menteri Nomor 30 Tahun 2011 Tentang Pedoman Umum Tata Kelola Kehumasan Di Lingkungan Instansi Pemerintah. Terdapat beberapa poin penting untuk digarisbawahi dalam peraturan tersebut, diantaranya adalah Tugas humas pemerintah adalah melaksanakan komunikasi timbal balik antara instansi pemerintah dan public yang terencana untuk menciptakan saling pengertian (mutual understanding) dalam mencapai tujuan, demi memperoleh maanfaat bersama. Fungsi humas pemerintah adalah menjadi penghubung instansi dengan publiknya melalui manajemen komunikasi. Kemudian, Peran humas pemerintah adalah sebagai komunikator, ia berperan membuka akses dan saluran komunikasi dua arah antara instansi pemerintah dan publiknya; menyerap aspirasi publik untuk dijadikan masukan dalam pembuatan kebijakan.

Agenda besar yang tersirat dari peraturan menteri di atas adalah menghendaki humas pemerintah untuk dapat menyelenggarakan pola komunikasi kehumasan yang bersifat dua arah, sehingga dengan begitu keterlibatan publik semakin nyata tampak dalam penyelenggaraan demokrasi Indonesia.

Untuk menjalankan sejumlah tugas, fungsi dan peran tersebut, Menteri Rudiantara meminta humas pemerintah agar memanfaatkan media sosial (ES, 2014). Peran penting media sosial akan tampak pada peningkatkan partisipasi masyarakat, munculnya inovasi baru, dan menciptakan model komunikasi yang mana pemerintah tidak hanya menyebarkan wacana politik kebijakan dan perencanaan (satu arah), melainkan juga unsur ketelibatan dalam model komunikasi dua arah yang seimbang (Srivastava, 2013). 
Lalu kemudian Kementerian PANRB mengeluarkan Peraturan Nomor 83 Tahun 2012 Tentang Pedoman Pemanfaatan Media Sosial Instansi Pemerintah. Amanah peraturan tersebut menghimbau agar humas pemerintah menggunakan media sosial sebagai saluran komunikasi dengan masyarakatnya, mengingat sejumlah keunggulan khusus yang dibawa oleh media sosial dan tidak dimiliki media lain seperti cetak dan elektronik.

Namun kenyataan tersebut membawa kita pada sebuah postulat bahwa model komunikasi dua arah antara pemerintah dan masyarakatnya, secara umum, belum benarbenar terlaksana di tingkat lokal. Di wilayah Sumatera Barat sendiri, biro humas tingkat provinsi termasuk yang belum mengadopsi paradigma humas baru. Pola-pola komunikasi yang ditempuh masih terbilang konvensional dan bersifat searah. Era digital yang tengah bergulir dan dikenal sebagai information and communication technology (ICT) ternyata tidak membawa konsekuensi berarti pada wajah komunikasi pembangunan Sumatera Barat.

Dalam konteks penelitian ini-setelah tujuh tahun sejak terbitnya Pedoman Tata Laksana Kehumasan (tahun 2011) terkait pelaksanaan model komunikasi kehumasan yang bersifat dua arah-sampai sekarang Biro Humas Setda Provinsi Sumatera Barat masih bertahan dalam model penyelenggaraan komunikasi kehumasan yang bersifat satu arah.

Penyelenggaraan model komunikasi dalam aktivitas kehumasan oleh Biro Humas Setda Provinsi Sumatera Barat yang bersifat linear ini menjadi asumsi tersendiri, sebagai suatu bukti atas dominasi yang dilakukan pihak pemerintah terhadap masyarakat. Manifestasi model komunikasi satu arah yang dilakukannya dalam praktik komunikasi massa-pelepasan ide-pesan dalam produk-produk jurnalistik kepada masyarakat melalui media yang ada-merupakan prosesi 'pemaksaan konstruksi ide dan realita'. Masyarakat tidak memiliki sumber daya komunikasi untuk dapat berhubungan dengan elit penguasa secara berimbang. Lebih jauh masyarakat hanya terpapar secara politis tanpa benar-benar menjadi bagian dari penyelenggaraan politik itu sendirikecuali 'sekadar' dalam pemilihan kepala daerah. Masyarakat jauh dari daulat yang menjadi haknya - kedaulatan ini sebenarnya milik siapa? Sementara itu di luar sana, dunia public relation memasuki babak barunya; ia lebih mengutamakan keterlibatan publik untuk dapat menyelesaikan konflik-konflik dan menimbulkan kesepahaman bersama berdasarkan Cutlip (2006).

Kenyataan saat sekarang menunjukkan bahwa terdapat jurang komunikasi antara pemerintah dan masyarakat Sumatera Barat dalam aktivitas komunikasi kenegaraan. Di lain sisi, faktor keterbukaan dan kelancaran komunikasi dalam proses pembangunan merupakan kunci perubahan sosial ke arah yang lebih baik. Masalah ini menjadi sebuah fenomena menarik untuk diteliti lebih jauh dengan seksama. Tata laksana humas pemerintahan lokal di Indonesia secara umum belum seperti model humas-baru yang 
dijelaskan Grunig sebelumnya. ${ }^{1}$ Sejauh ini peran media sosial di dalamnya masih sangat minim. Beberapa pemerintah daerah memang telah memiliki akun di beberapa media sosial seperti Facebook, Twitter dan Youtube. Akan tetapi, mayoritas dari pemerintah daerah di Indonesia belum mengembangkan pemanfaatan akun media sosial sebagai media pendukung - apalagi menjadi yang utama - dalam penyelenggaraan komunikasi pemerintahan. Jika dicermati lebih jauh, faktanya memang masih banyak lembaga maupun instansi pemerintah daerah yang belum memanfaatkan media sosial sebagai media komunikasi organisasi. Sebagian besar hanya menyediakan informasi dengan gerak lambat dan jarang diperbarui-terutama situs-situs web pemerintahan provinsi dan kota/kabupaten. Maka dari itu tidaklah keliru jika keseriusan pemerintah lokal dianggap belum sungguh-sungguh dalam menyelenggarakan komunikasi modern yang berorientasi publik.

Keniscayaan yang jelas tampak di sini bahwa penggunaan media yang dipilih oleh Biro Humas Setda Provinsi Sumatera Barat menjelaskan bagaimana mereka memainkan model komunikasi. Ini bukan keadaan yang tidak dapat dielakkan, penulis mendapatkan indikasi bahwa hal tersebut merupakan pilihan yang dipilih dengan sangat sadar oleh praktisi Biro Humas Setda Provinsi Sumatera Barat. Temuan dalam observasi dan wawancara awal menyatakan bahwa dalam tataran pelaksanaan sama sekali tidak menyentuh bentuk penyelenggaraan humas modern yang ideal sesuai dengan yang diamanatkan perundangan yang ada.

\section{METODE}

Pendekatan kritis dalam berbagai studi kehumasan secara terpusat memiliki fokus terhadap isu kekuasaan. Seperti yang Trujilo dan Toth (1987) katakan, perspektif 'memperlakukan humas sebagai ideologi dan arena materi demi kekuasaan, pengaruh, dan control; dan mereka memperlakukan publik organisasi sebagai koalisi dan konstituen yang memiliki keberagaman kepentingan, nilai dan perspektif'. Nilai perspektif kritisnya adalah bahwa mereka menginvestigasi bagaimana politik, sosiokultural, dan kondisi ekonomi membentuk praktik humas dan menegaskan 'sumber kekuasaan dan pengaruhnya' yang praktisi humas wakili. Yang sama pentingnya adalah isu-isu yang terfokus pada bagaimana praktik humas dapat mempromosikan nilai tertentu yang menyesuaikan dengan hal politis yang khusus, ekonomi, dan kerangka kerja budaya serta gaya hidup, akan tetapi tidak dengan yang lainnya. Ini pada gilirannya membawa pada sebuah aktivitas mempertanyakan peran humas dan tanggung jawabnya terhadap masyarakat yang demokratis. Lebih lanjut Motion dan Weaver menjelaskan bahwa koridor utama dari kepentingan humas ialah menyediakan dan membentuk 'makna tertentu' di mata masyarakat, politik budaya, dan bernilai ekonomis untuk menguntungkan pihak yang mendominasi. 
Kajian humas kritis juga jelas berbicara tentang motif-motif ekonomi politik. Teori ekonomi politik bekerja pada kekuatan modal dan proses komodifikasi sebagai pijakan awal analisis sosialnya. Sehingga sentuhan perspektif kritis di sini dapat menyingkap bagaimana humas berpartisipasi dalam mengupayakan kegiatan mengatur dan mengontrol sumber-sumber kekuasaan sebagai sebuah strategi hegemonik. Melalui hegemoni, penulis berbicara tentang suatu pertarungan tanpa kekerasan untuk menjaga berbagai kepentingan kekuasaan seperti ekonomi, politik, budaya, dan ideologi. Oleh sebab itulah humas memainkan peran melalui pemberitaan di media sebagai suksesor penguasa.

Strategi kunci bagaimana humas berkontribusi dalam melanggengkan hegemoni kekuasaan ialah melalui artikulasi, disartikulasi, maupun reartikulasi elemen-elemen dalam sebuah wacana pemberitaan. Ini menjadi kesibukan utama humas pemerintah daerah di Indonesia pada umumnya.

\section{Koalisi Dominan Dalam Public Relations}

Sejumlah referensi mengatakan bahwa mereka begitu kuat dan berpengaruh dalam praktik kehumasan. Dengan narasi pembuka yang lantang, Berger (2005) bahkan memulai penelusuran kritisnya tentang kekuasaan dan koalisi dominan melalui teori komunikasi simetris Grunig yang idealis itu, "Symmetrical public relations theory acknowledges primacy of the dominant coalition in making organizational decisions and influencing public relations practices but reveals little about this powerful inner circle. ... it is complex power relationships."

Koalisi dominan merupakan konsep yang sangat esensial dalam teori-teori kehumasan dan organisasi. Asumsi kunci dalam tataran ini menurut Larisa dan James Grunig (dalam Berger, 2005) yaitu bahwa keberadaan koalisi dominan akan membantu praktisi humas melakukan 'hal yang benar' saat praktisi humas tersebut dihitung dan masuk ke dalam lingkaran koalisi dominan-mereka akan mencoba untuk mewakili suara dan kepentingan orang banyak. Kemudian praktisi humas tersebut juga akan turut serta bersama koalisi dominan membentuk ideoologi organisasi dan keputusan demi menguntungkan organisasi serta masyarakat luas.

\section{Konsep Hegemoni}

Konsep yang satu ini berasal dari catatan Antonio Gramsci selama dipenjara beberapa tahun lamanya, Selection from Prison Notebooks (1971). Gramsci menganalisa berbagai relasi kekuasaan dan penindasan di masyarakat. Lewat perspektif hegemoni, akan terlihat bahwa penulisan, kajian suatu masyarakat, dan media massa merupakan alat kontrol kesadaran yang dapat digunakan kelompok penguasa.

Melalui konsep power over relations, Berger (2005) menyebut hegemoni sebagai suatu bentuk non-koersif dominasi yang mana di dalamnya kelompok 
subordinat secara aktif rela dan mendukung sistem kepercayaan serta struktur hubungan kekuasaan yang tidak semestinya melayani kepentingan koalisi dominan. Sementara itu, sudut pandang critical public relations menyajikan kilatan bagaimana public relations berpartisipasi dalam mengupayakan pengaturan atau kontrol sumber-sumber kekuasaan (materil dan simbolik) sebagai sebuah strategi dominasi (Motion dan Weaver, 2005). Dari hegemoni tersebut Motion dan Weaver bermaksud mengangkat realita pertarungan-tanpa-kekerasan dalam menjaga kekuasaan secara ekonomi, politis, budaya, dan ideologis. Lalu kemudian untuk membangun, menjaga, atau mengubah bentuk hegemoni kekuasaan, di sinilah public realtions berperan dalam memainkan wacana untuk memutar ide-ide di wilayah publik (melalui media), membangun hubungan yang menguntungkan, dan mengultuskan suatu kebenaran semu demi kepentingan. Strategi kunci bagaimana public relations berkontribusi dalam melanggengkan hegemoni kekuasaan ialah melalui artikulasi, disartikulasi, maupun reartikulasi elemen-elemen dalam sebuah wacana pemberitaan.

\section{Excellence Theory: Sebuah Perspektif Dalam Menganalisis Model Komunikasi Kehumasan}

Berbicara tentang konsep excellence, ia merupakan hasil penelitian dari James E. Grunig dan tim selama 15 tahun (Grunig, 2002). ${ }^{2}$ Teori ini merupakan pengembangan dari empat model kehumasan melalui model komunikasinya yang diperkenalkan Grunig dan Hunt dalam bukunya Managing Public Relations (1984). Keempat model tersebut diidentifikasi sebagai model yang diterapkan praktisi kehumasan dalam menjalin hubungan dengan publik. Model ini juga dapat disebut sebagai tipe proses kegiatan humas. Keempat model tersebut ialah press agentry, pulic information, two-way asymmetric, dan two-way symmetric model.

Tyma (2008) menyatakan bahwa excellence theory dikembangkan dan secara berkelanjutan diuji untuk mendapatkan apa yang membuat praktik kehumasan berjalan efisien dan etis untuk seluruh pihak yang terlibat. Lebih jauh ia berpendapat bahwa untuk mencapai keadaan itu, diperlukan criticism yang bertujuan untuk membongkar teori-teori yang tidak lagi relevan dalam aplikasi nyata lingkup sosial humas, aspek politik humas, atau realita-realita yang ditemukan baik oleh praktisi kehumasan atau peneliti.

\section{HASIL DAN DISKUSI}

\section{Realita Penyelenggaraan Model Komunikasi Searah Oleh Biro Humas Setda Provinsi Sumatera Barat}

Biro Humas Sekda Provinsi Sumatera Barat menerapkan model komunikasi searah dalam aktivitas komunikasi kehumasannya. Komunikasi searah seperti yang telah diuraikan sebelumnya menggunakan siaran pers dan teknik komunikasi satu arah 
lainnya untuk menyebarkan informasi organisasi. Hal ini menimbulkan keadaan komunikasi yang searah. Biro Humas Sekda Provinsi Sumatera Barat hanya sekedar memberikan informasi saja, tanpa melihat lebih jauh peran penting balasan atau feedback dari masyarakat Sumatera Barat terkait. Dari paparan data yang telah penulis sampaikan pada bagian sebelumnya, media massa seperti koran menjadi alat utama yang digunakan oleh pemerintah provinsi Sumatera Barat. Dalam hubungannya, antara media massa dengan Biro Humas Sekda Provinsi Sumatera Barat telah terjalin sebuah kerjasama yang terbilang cukup lama dan saling menguntungkan. Pemerintah provinsi dapat dengan leluasa menggunakan media massa menjadi alat propaganda untuk menyampaikan berbagai misi dan kegiatan yang dilakukan oleh pemerintah daerahtermasuk kepala daerah, seperti implementasi sebuah kebijakan, keberhasilan kepala daerah, dan banyak lagi lainnya. Untuk tujuan tersebut Biro Humas Sekda Provinsi Sumatera Barat memperoleh dana yang sangat besar yang diambil dari dana Anggaran Pendapatan Belanja Daerah (APBD).

Hal tersebut menjadi kurang efektif ketika manajemen yang seharusnya mengelola Biro Humas Sekda Provinsi Sumatera Barat tidak berjalan maksimal sesuai tupoksi atau tugasnya sebagai organisasi yang mengoordinasi dan memfasilitasi hubungan masyarakat. Yang menjadi fokus utama Biro Humas Sekda bahwa yang terpenting itu adalah produktivitas berita, bagaimana membuat berita baik sebanyak mungkin untuk membangun reputasi kepala daerah. Secara tersirat, ia menyampaikan bahwa telah melakukan usaha terbaik untuk 'melayani' wartawan yang mampir ke biro humas. Namun pada akhirnya tetap tidak mampu meredam pemberitaan negatif yang muncul ke permukaan dan merugikan gubernur. Hal ini merupakan keadaan yang sebenarnya dari aktivitas Biro Humas Setda Provinsi Sumatera Barat. Hanya disibukkan oleh pemberitaan koalisi dominan. Pun begitu, masih selalu 'terancam' oleh pemberitaan negatif di media cetak.

Humas Provinsi Sumatera Barat hanya berfungsi sebagai pelayan kepala daerah saja. Tugas pokok humas hanya untuk penyeimbang berita negatif dan kemudian melakukan counter agar reputasi pimpinan tetap baik di mata masyarakat. Menurut penulis, hal ini disebabkan karena model komunikasi utama yang dimainkan adalah model searah yang melalui media massa. Masalah lainnya yakni tidak semua media massa yang ada di Sumatera Barat menjadi rekanan pemerintah, sehingga pemberitaan seluruh media yang ada tersebut menjadi beragam — tidak melulu memberitakan hal-hal baik mengenai kinerja pemerintah kepada masyarakat. Disinilah kemudian biro humas difungsikan oleh koalisi dominan. Biro humas akan 'melayani' jurnalis yang datang dari berbagai media dan memberikan klarifikasi terkait pemberitaan yang sedang berkembang - berita yang berkaitan dengan citra dan reputasi kepala daerah saja.

Keberadaan Biro Humas Sekretariat Daerah Provinsi Sumatera Barat adalah untuk mendukung jalannya roda pemerintahan, terciptanya masyarakat informatif, serta terbentuknya citra positif pemerintah daerah, yang dapat mendorong partisipasi 
masyarakat dalam setiap kegiatan pembangunan yang sesuai dengan amanat perundangan yang ada. Lebih lanjut, berdasarkan Renstra Biro Humas 2010 - 2015, ${ }^{3}$ terciptanya masyarakat yang informatif dan partisipatif melalui reformasi birokrasi untuk mewujudkan pemerintahan daerah yang baik, bersih dan profesional merupakan visi dari Biro Humas Sekda Pemerintahan Provinsi Sumatera Barat. Masyarakat informatif yang dimaksud disini adalah suatu kehidupan masyarakat yang serba modern tidak akan lepas dari peran media dan informasi. Salah satu peran media bagi manusia adalah untuk menjalin relasi atau koneksi dengan orang lain. Dalam konteks inilah, media dan informasi menjadi penting agar komunikasi berjalan dengan baik. Sedangkan partisipatif yang dimaksud di sini, masyarakat berperan secara aktif dalam proses atau alur tahapan program dan pengawasannya, mulai dari tahap sosialisasi, perencanaan, pelaksanaan, dan pelestarian kegiatan dengan memberikan sumbangan tenaga, pikiran, atau secara materill terhadap pelaksanaan program dan kegiatan pembangunan yang dilakukan pemerintah.

Reformasi birokrasi yang dimaksud ialah dengan melakukan perubahan dan pembaharuan dalam penyelenggaraan pemerintah daerah pada kegiatan komunikasi dan informasi. Upaya kegiatan reformasi biokrasi bidang komunikasi dan informasi penyelenggaraan pemerintah daerah ini sebagai upaya mewujudkan penyelenggaraan pemerintah yang baik, bersih dan professional, sehingga mampu meningkatkan kepercayaan publik kepada penyelenggaran pemerintah. Pemerintah daerah yang dimaksud disini adalah penyelenggaraan urusan pemerintahan oleh pemerintah daerah menurut asas otonomi dan tugas pembantuan dengan prinsip otonomi seluas-luasnya dalam sistem dan prinsip Negara Kesatuan Republik Indonesia sebagaimana dimaksud dalam Undang-Undang Dasar Negara Republik Indonesia Tahun 1945.

\section{Hambatan Internal Dalam Mewujudkan Komunikasi Dua Arah}

Untuk mewujudkan sistem komunikasi yang bagus, pemerintah seharusnya menerapkan sistem komunikasi dua arah yang seimbang, dan sesekali menggunakan sistem dua arah yang tidak seimbang tentu saja dapat diterima. Hal ini terutama dalam penerapan sebuah kebijakan atau peraturan pemerintah. Respons masyarakat tentu saja dibutuhkan dalam mengkaji apakah sebuah kebijakan dan peraturan tersebut pantas dan layak diterapkan di tengah masyarakat. Hal ini bertujuan agar pada saat sebuah kebijakan dan peraturan diimplementasikan di tengah masyarakat, tidak lagi terjadi penolakan dan protes dari masyarakat. Namun dalam menerapkan model komunikasi dua arah ini tentunya dibutuhkan kesiapan mental yang cukup kuat dari organisasi yang berkepentingan, yang dalam kasus ini adalah pemerintah provinsi Sumatera Barat, khususnya Biro Humas Sekda Provinsi Sumatera Barat. Gubernur sebagai pucuk pimpinan tertinggi dan decision maker dalam jajaran struktural pemerintahan provinsi harus menjadi pionir dalam perubahan ini. 
Biro humas berada dalam situasi dilematis. Di sisi lain, wakil gubernur juga tak kalah heboh jika pemberitaan dirinya jauh terpaut dari jumlah pemberitaan gubernur. hal utama yang paling dibutuhkan adalah kepiawaian biro humas dalam menjaga komunikasi tetap berada pada jalur yang diinginkan, tidak melebar ke mana-mana. Jika dilihat sekilas dan secara garis besar, komunikasi dua arah bisa dianggap bentuk komunikasi yang ideal karena memungkinkan kedua belah pihak memberikan pandangan atau minimal respons mereka terhadap pesan yang disampaikan. Dibanding komunikasi satu arah yang mungkin tampak terlihat dominan dan tidak adil untuk semua pihak yang berada dalam proses komunikasi, komunikasi dua arah memang memberikan lebih banyak opsi untuk munculnya perbincangan, mutual understanding, dan pembahasan lebih lanjut mengenai pesan atau topik yang dikomunikasikan.

Pada dasarnya, tahapan dan indikator dalam komunikasi dua arah saling berkaitan satu sama lain.

Pertama, pembuatan atau kepemilikan gagasan atau ide dasar oleh pemberi atau sumber pesan (source). Dalam hal ini, Biro Humas Sekda Provinsi Sumatera Barat adalah sebagai pemberi pesan atau source. Idealnya, pada tahapan pertama biro humas yang merupakan perpanjangan tangan pemerintah provinsi sudah memiliki ide atau gagasan bagaimana menyampaikan sebuah pesan atau menyosialisasikan sebuah kebijakan, yang memang dimaksudkan untuk disampaikan kepada masyarakat Sumatera Barat, sebagai target atau calon penerima pesan. Tahapan selanjutnya, biro humas mengolah gagasan atau ide tersebut menjadi pesan yang dapat lebih mudah disampaikan serta dipahami oleh masyarakat Sumatera Barat. Selanjutnya, biro humas menyampaikan pesan tersebut kepada masyarakat sebagai receiver atau penerima pesan dengan menggunakan sebuah channel atau saluran yang dianggapnya sesuai. Proses ini sangatlah penting karena berperan besar dalam menentukan apakah pesan dapat tersampaikan dan diterima dengan baik atau tidak. Hal yang perlu diingat adalah bahwa apa yang disampaikan mungkin saja tidak sama dengan apa yang diterima. Hal ini disebabkan karena adanya faktor-faktor lain yang turut menentukan.

Kemudian, setelah penerima pesan (masyarakat) memahami dan memaknai isi dari pesan yang sudah diterimanya biro humas, maka akan banyak faktor internal dari masyarakat yang akan turut mempengaruhi, seperti pandangannya akan suatu hal atau pengalamannya di masa lalu terhadap suatu peristiwa. Jadi bisa saja makna yang dimiliki masyarakat terhadap pesan berbeda dengan makna yang dimiliki oleh biro humas.

Setelah memahami dan memaknai pesan, masyarakat kemudian memberikan feedback atau respons yang ia miliki terhadap pesan tersebut. Respons ini bisa saja berupa tanggapan terhadap pesan, atau justu pertanyaan karena ada hal yang dianggap belum jelas. Bahkan tidak jarang berupa kritik terhadap pesan tersebut. Dalam tahap ini, harapan yang diinginkan adalah kedua belah pihak bisa berupaya menyamakan 
pandangan terhadap makna pesan dan melakukan diskusi terhadap isi pesan tersebut demi pemahaman bersama (mutual understanding).

Ketimpangan komunikasi politik yang terjadi antara Biro Humas Sekda Provinsi Sumatera Barat dengan masyarakat seharusnya terjalin dalam bentuk ideal-sistem komunikasi dua arah diagonal. Karena, sesungguhnya sangat jelas antara pemerintah dan masyarakat mempunyai kedudukan dan wewenang yang berbeda. Masyarakat adalah sebagai pemberi kepercayaan kepada pemerintah, dan pemerintah dalam kedudukannya sebagai pengemban kepercayaan masyarakat untuk menjalankan roda pemerintahan daerah sekaligus sebagai otoritas yang memberikan pelayanan kepada masyarakat. Oleh karena itu setiap kebijakan yang dilahirkan pemerintah provinsi sudah sepatutnya berdasarkan kebutuhan dan keinginan masyarakat. Lalu sebelum suatu kebijakan atau peraturan tersebut diberlakukan, diperlukan sebuah sosialisasi oleh pemerintah sebagai pembuat kebijakan, untuk melihat respons masyarakat -apakah sebuah kebijakan dan peraturan tersebut telah benar-benar sesuai dengan kebutuhan masyarakat Sumatera Barat. Tidak cukup sampai disitu, bagian terpenting yakni dengan menciptakan kanal-kanal komunikasi digital di mana masyarakat dapat memberikan feedback kapan dan dari mana saja.

Dari fakta krisis kerja serta fungsi Biro Humas Sekda Pemerintah Provinsi Sumatera Barat dewasa ini, dapat dikatakan menyalahi dan melanggar asas tata kelola kehumasan di lingkungan instansi pemerintah. Sudah sepatutnya mendapat evaluasi dari pemberi amanah kerja, yaitu gubernur. Namun di sinilah anomali politik terjadi, gubernur adalah pemimpin dari koalisi dominan yang mendominasi biro humas itu sendiri. Humas hari ini 'hanya' sebagai pelayan kepala daerah, tanpa mementingkan masyarakat informatif dan komunikatif yang mampu menyerap dan merespon balik isuisu kontemporer penting seperti pembangunan, ekonomi, sosial, dan budaya dengan sistem government to citizen maupun citizen to government.

Jadi komunikasi pemerintahan pada hakekatnya merupakan proses penyebaran dan pertukaran informasi di dalam dan dengan luar organisasi. Melalui komunikasi pemerintahan, maka eksekutif pemerintahan bertukar dan membagi informasi dengan yang lain, yaitu dengan legislatif, dengan staf, dengan pelaku bisnis, dan dengan masyarakat. Melalui komunikasi, eksekutif pemerintah atau administrator atau manajer pemerintah bermaksud untuk mempengaruhi sikap (attitude), pemahaman (understanding), dan perilaku (behavior) birokrasi dan masyarakat. Dengan demikian, tiap orang yang terlibat dalam penyelenggaraan pemerintahan demokratis merupakan bagian dari proses komunikasi pemerintahan, baik sebagai sender di satu waktu, dan di waktu lain ia menjadi receiver.

Bahkan, komunikasi dua arah dalam pemerintahan tidak saja sebagai sarana atau alat bagi pemerintah untuk menyampaikan atau menerima informasi tentang suatu kebijakan publik, misalnya, tetapi juga sebagai sarana untuk memadukan kegiatan- 
kegiatan secara terorganisasi dalam mewujudkan kerjasama antara pemerintah dengan pihak-pihak lainnya. Komunikasi tersebut juga merupakan sarana penyaluran masukan sosial ke dalam sistem pemerintahan, dan sarana mempengaruhi perubahan, memproduktifkan informasi, juga sarana untuk mencapai tujuan serta membantu pelaksanaan dan memadukan fungsi-fungsi manajemen pemerintahan.

\section{KESIMPULAN}

\section{Kesimpulan}

Praktik penyelenggaran humas di lingkungan instansi pemerintah, khususnya Biro Humas Sekda Provinsi Sumatera Barat sedang dalam krisis dan jauh dari ekspektasi. Krisis di sini diartikan sebagai krisis kinerja yang jauh dari amanat perundangan yang mengatur. Peraturan Menteri PANRB Nomor 30 Tahun 2011 Tentang Pedoman Umum Tata Kelola Kehumasan Di Lingkungan Instansi Pemerintah tidak berjalan — nyatanya terpenuhi hanya sebagian kecil saja, yakni fungsi diseminasi, namun itu pun didominasi oleh pemberitaan menyangkut pembentukan citra pimpinan. Kondisi ini jelas berdampak pada jalannya roda pembangunan. Komunikasi antara masyarakat dengan pemerintah adalah sebuah keharusan jika berbicara dalam tataran demokrasi.

Biro Humas Sekda Provinsi Sumatera Barat sebagai unit kerja yang sangat strategis telah kehilangan fungsi sebagai mana mestinya. Hal ini disebabkan oleh beberapa hal, pertama, dominasi yang ia terima dari kelompok berkuasa mengharuskannya berlaku tidak sesuai dengan tugas dan fungsi yang telah diatur perundangan. Hal tersebut menyiratkan humas adalah wadah untuk menunjukkan dan mempertahankan kekuasaan oleh koalisi dominan. Kedua, kurangnya pikiran untuk maju dan mengikuti perubahan zaman oleh karena disibukkan selalu oleh upaya menjaga citra pimpinan melalui pemantauan dan produksi berita. Nilai-nilai kehumasan modern yang lebih baik telah ada dan dirumuskan demi terciptanya komunikasi yang berimbang antara masyarakat. Ini bukan kebuntuan-hanya kealfaan berpikir ke arah yang lebih modern.

Ketiga, era industri pers semakin menjerat Biro Humas Sekda Provinsi Sumatera Barat. Ketergantungan antara biro humas dengan media, pun sebaliknya, menciptakan lingkaran kemunduran yang tak berkesudahan. Biro humas selalu takut jika ada pemberitaan negatif tentang koalisi dominan, sehingga ia 'berteman baik' dengan media cetak. Media cetak juga butuh pemasukan dan memiliki senjata ampuh untuk menjamin kebutuhannya terpenuhi-pemberitaan negatif. Kepala daerah sangat memikirkan reputasinya agar selalu baik dari pada komunikasi pembangunan yang semestinya berjalan baik dengan masyarakat. Memelihara dan memepertahankan kekuasaan bukanlah hal yang haram, akan tetapi meletakkan kepentingan masyarakat menjadi hal yang tidak terlalu penting merupakan kesalahan besar dalam sudut pandang kenegaraan. 
Biro Humas Sekda Provinsi Sumatera Barat dalam posisi mendominasi masyarakat secara wacana, sekaligus terdominasi oleh koalisi dominan yang berada di atasnya. Kondisi ini telah berlangsung lama dan sulit sekali diubah. Regulasi yang mengatur sudah sangat baik, akan tetapi aparat yang menjalankan dipenuhi belenggu oleh kekuatan-kekuatan yang berpengaruh. Bukannya tidak ada orang di tubuh Biro Humas Sekda Provinsi Sumatera Barat yang mengerti tentang apa yang seharusnya dilakukan. Tentu ada. Akan tetapi pada akhirnya, penulis merasa miris, sepertinya semua berlaku dan kembali kepada pragmatisme - bahwa kebenaran bergantung pada penerapannya bagi kepentingan masing-masing.

\section{Saran}

Penyelenggaraan model komunikasi searah dalam aktivitas kehumasan Biro Humas Sekda Provinsi Sumatera Barat jauh dari ideal. Beberapa langkah konkrit perlu dilakukan segera untuk dapat menciptakan model humas modern yang sarat dengan komunikasi dua arah berimbang. Pertama, koalisi dominan yang notabene merupakan gubernur Sumatera Barat dan wakilnya harus secara nyata mengimplementasikan amanah yang terdapat dalam Peraturan Menteri Nomor 30 Tahun 2011 Tentang Pedoman Umum Tata Kelola Kehumasan Di Lingkungan Instansi Pemerintah. Dari hulu, harus kembali kepada produk hukum yang mengatur. Biro Humas Sekda Provinsi Sumatera Barat akan selalu menuruti perintah dari atas mengikuti hirarki kepemimpinan dalam birokrasi pemerintahan. Kedua, memperbaiki mindset lama dengan sebuah pemikiran bahwasanya pemerintah ada untuk menjadi abdi masyarakat. Etika publik aparatur harus dijunjung tinggi. Kesadaran ini merupakan sikap mental yang mutlak untuk mewujudkan perubahan dalam penyelenggaraan kehumasan di lingkungan pemerintah. Ketiga, dengan adanya pemikiran yang maju dan modern di tubuh pemerintah, akan membuat pemerintah menjadi tahu mana langkah yang efektif dan efisien serta mana yang tidak. Pemerintah akan dapat mengevaluasi dan mempertimbangkan penggunaan media yang dapat memfasilitasi komunikasi yang bersifat dua arah bersama masyarakatnya. Ini juga secara perlahan melonggarkan ikatan kuat yang selama ini terjadi antara Biro Humas Sekda Provinsi Sumatera Barat bersama media cetak.

\section{REFERENSI}

Akral. Transkrip Wawancara. 28 September 2016, Kantor Gubernur Sumatera Barat, Padang.

Berger, Bruce K. (2005). Power Over, Power With, and Power to Relations: Critical Reflections on Public Relations, the Dominant Coalition, and Activism. Journal Of Public Relations Research, 17(1), 5-28. www.tandfonline.com. Diakses tanggal 22 April 2016. 
Biro Humas Sekda Provinsi Sumatera Barat. Rencana Strategis Biro Humas 2010 2015. Padang, Sumatera Barat.

COI. (2009). Engaging Through Social Media: A Guide For Civil Servants. London: Hercules House. http://www.politicheeuropee.it/file/955. Diakses tanggal 6 Maret 2016.

Cutlip, Center and Broom. (2006). Effective Public Relations. Jakarta: Kencana Prenada Media Group.

Gramsci, A. (1971). Selections From The Prison Notebooks of Antonio Gramsci. Q. Hoare \& G. Nowell Smith, Trans. New York: International.

Grunig, E. James \& Todd Hunt. (1984). Managing Public Relations. Rinehart \& Winston.

Grunig, E. James. (2009). Paradigms of Global Public Relations In An Age of Digitalisation. Prism Journal 6(2). http://praxis.massey.ac.nz/prism_online_journ.html. Diakses tanggal 7 Maret 2016.

Grunig, L. A., J. E. Grunig \& M. D. Dozier. (2002). Excellence Public Relations and Effective Organizations: A Study of Communication Management in Three Countries. Lawrence Erlbaum. Mahwah, New Jersey.

Motion, Judy., Weaver, C. Kay. (2005). A Discourse Perspective For Critical Public Relations Research: Life Science Network And The Battle For Truth. Journal Of Public Relations Research, 17(1), 49-67. http://scholar.google.com/scholar_url?url=http://citeseerx.ist.psu.edu/. Diakses tanggal 2 Desember 2015.

Pemerintah Provinsi Sumatera Barat. (2016). Dokumen Pelaksanaan Anggaran Satuan Kerja Perangkat Daerah (DPA-SKPD) Biro Humas Sekretariat Daerah Provinsi Sumatera Barat Tahun Anggaran 2016. Padang.

Peraturan Menteri Pendayagunaan Aparatur Negara Dan Reformasi Birokrasi Republik Indonesia Nomor 83 Tahun (2012) Tentang Pedoman Pemanfaatan Media Sosial Instansi Pemerintah.

Peraturan Menteri Pendayagunaan Aparatur Negara Dan Reformasi Birokrasi Republik Indonesia Nomor 30 Tahun 2011 Tentang Pedoman Umum Tata Kelola Kehumasan Di Lingkungan Instansi Pemerintah.

Roni. (2016). Transkrip Data Wawancara Mendalam. Padang, Sumatera Barat.

Satria, Novandre. (2016). Transkrip Data Wawancara Mendalam. Padang, Sumatera Barat.

Satria, Novandre. (2016). Transkrip Data Wawancara Observasi Awal Kedua. Padang, Sumatera Barat. 
Satria, Novandre. (2016). Transkrip Data Wawancara Observasi Awal Pertama. Padang.

Srivastava, Meetika. (2013). Social Media And Its Use By The Government. Journal of Public Administration and Governance, ISSN 2161-7104 2013, Vol.3 No. 2. http://www.macrothink.org/journal/index.php/jpag/article/. Diakses tanggal 16 Februari 2016.

Tyma, W. Adam. (2008). Public Relations Through New Lens: Critical Praxis via the Excellence Theory. International Journal of Communication 2, 193-205. http://digitalcommons.unomaha.edu/commfacpub/27. Diakses tanggal 27 Februari 2016.

UI, Puskakom. (2015). Profil Pengguna Internet Indonesia 2014. Riset Asosiasi Penyelenggaran Jasa Internet Indonesia (APJII). www.slideshare.net. Diakses tanggal 8 Desember 2015. 